\section{Commentary: Medical malpractice litigation for aortic dissection: Heads they win; tails we lose}

\author{
Krystal R. Ikonomidis, RN, BSN, JD, and
}

John S. Ikonomidis, MD, PhD

Any surgical lawsuit, successful or otherwise, is a loss to the surgeon implicated. Whether lost on the merits, settled outside of court, or even where the court finds favorably for the surgeon, medical litigation never results in a true "win" for the provider, as the mere filing of the suit itself is associated with tremendous stress, foreseeable insurance premium increases, and the ever-dreaded "mark on the record" for the remainder of one's career, regardless of the outcome. As doctors are never truly "winners" in such scenarios, it is helpful to understand and anticipate factors that lead to medical litigation in effort of avoiding the same.

In this issue of the Journal, Palaniappan and Sellke ${ }^{1}$ used the Westlaw database to identify 135 cases of medical malpractice litigation related to aortic dissection over a 25-year period, 1994 to 2019. Of these cases, a defendant verdict was reached in $57 \%(\mathrm{n}=77)$, plaintiff verdict in $20 \%(n=27)$, and settlements in $23 \%(n=31)$. Plaintiffs most commonly cited a failure to diagnose as their reason for litigation in 64\% $(n=87)$. Patient mortality was associated with a lower average plaintiff award, and a lower average settlement, than their surviving counterparts. An alleged failure to test, failure to refer, failure to consult, incidence of a stroke, and incidence of an autopsy diagnosis were significantly associated with defendant verdicts.

This study showed that roughly half of known litigation arising from alleged aortic dissection-related medical malpractice results in dispositions rendered against medical

\footnotetext{
From the Division of Cardiothoracic Surgery, University of North Carolina at Chapel Hill, Chapel Hill, NC.

Supported by the funding sources National Institutes of Health/National Heart, Lung, and Blood Institute grants 2R01HL102121 and 1R21HL148363.

Disclosures: The authors reported no conflicts of interest.

The Journal policy requires editors and reviewers to disclose conflicts of interest and to decline handling or reviewing manuscripts for which they may have a conflict of interest. The editors and reviewers of this article have no conflicts of interest.

Received for publication Oct 28, 2020; revisions received Oct 28, 2020; accepted for publication Oct 28, 2020; available ahead of print Nov 5, 2020.

Address for reprints: John S. Ikonomidis, MD, PhD, Division of Cardiothoracic Surgery, University of North Carolina at Chapel Hill, 3034 Burnett Womack Building, 160 Dental Circle, Chapel Hill, NC 27599-7065 (E-mail: john_ikonomidis@med. unc.edu).

J Thorac Cardiovasc Surg 2022;164:609-10

$0022-5223 / \$ 36.00$

Copyright (c) 2020 by The American Association for Thoracic Surgery

https://doi.org/10.1016/j.jtcvs.2020.10.115
}

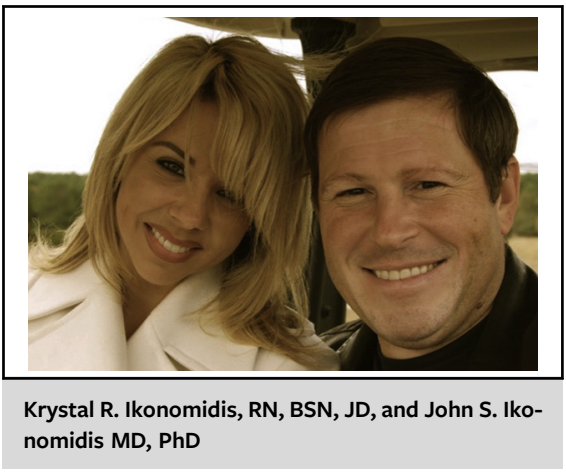

CENTRAL MESSAGE

A study that successfully presents a synopsis of common findings in medical malpractice litigation cases that have been filed involving aortic dissection is reviewed.

providers and/or settlement. Although settlements are not a direct victory for plaintiffs, nor do they solidify wrongdoing, they are nonetheless highly problematic for defendant clinicians, as discussed previously. The very real issue of aortic dissection-related lawsuits and the negative impact that they have on practitioners, regardless of their outcome, validates the importance and timeliness of this study.

The authors acknowledge the study's inherent limitation in that it captures only a small portion of litigation in this area. Westlaw, the legal database used, is in the opinion of many legal scholars and practitioners the gold standard for case review. Although not perfect, it is likely the best tool on the market. No database exists encompassing every example of alleged aortic dissection-related malpractice filed, contemplated, or settled outside of court. What Westlaw does provide, however, is a framework of the process for review, the binding rules of law that attorneys and judges will convey to the triers of fact should a suit progress to trial, and an analysis of what the courts considered to the applicable standard of care. Importantly, it sheds much needed light on the critical question of trends that indicates why the suits were filed, regardless of their ultimate disposition. This information is crucial in not only in preparing a defense should one find oneself defending such a case, but also in how to avoid committing what courts have determined to be malpractice. The authors were successful in identifying current trends for seeking legal action related to aortic dissection, specifically a delay in diagnoses and timely, appropriate treatment. The purpose of this study was 
not to illustrate the incidence of this type of lawsuit, but rather to provide a synopsis of common findings in cases that have been filed and this was accomplished.

Having said that, a deeper dive into these findings would be beneficial through provision of specific case citations and references from the cases. It would be interesting to get a feel for how many of those cases, if any, were appellate level, setting precedent for lower courts in terms of the rules of law implemented or elements to consider in determining an acceptable standard of care. As an appellate court ruling could overturn and set a new standard for previous rulings of lower courts, an understanding of the level and jurisdiction of the courts is helpful.

Further, it would also be helpful to have a table delineating the specific cases in the sampling considered for additional review, as cases are not always disposed of based on the finding of issue alone. That is, a decision in favor of the plaintiff may or may not be solely due to a substantive finding of malpractice on part of the surgeon, but could rather be based on another aspect of care provided, another provider entirely, or a procedural issue with the filing of the suit itself, etc. In other words, it is not enough to simply state for which party the court found favorably. A consideration of why the court made its finding is necessary to get an accurate picture of the dynamics at play with this particular type of litigation. This information would provide greater direction to surgeons seeking to use these opinions to better protect themselves from legal action related to aortic dissections, further accomplishing the goal of the authors.

\section{Reference}

1. Palaniappan A, Sellke F. Medical malpractice litigations involving aortic dissection. J Thorac Cardiovasc Surg. 2022;164:600-8.
See Article page 600.

\section{Commentary: Ambushed by a snow leopard: Malpractice litigations involving aortic dissection}

\section{Stephanie L. Mick, MD, and Leonard N. Girardi, MD}

When the Marfan Foundation established Aortic Disease Awareness Day in 2016, their leadership selected the snow leopard as the archetypal predator to represent aortic conditions: it is rare, silent, and difficult to find. With an incidence of approximately 7.7 cases/year per 100,000 population, ${ }^{1}$ the human predator known as acute aortic dissection is an uncommon but lethal entity that commonly involves multiple organ systems. Its most common variant, acute type A dissection (ATAAD), can be challenging to diagnose, as malperfusion syndromes may mimic stroke, myocardial infarction, mesenteric ischemia, or threatened limb. The "Great Masquerader," ATAAD often leads physicians down alternative diagnostic

From the Department of Cardiothoracic Surgery, Weill Cornell Medicine, New York, NY

Disclosures: The authors reported no conflicts of interest.

The Journal policy requires editors and reviewers to disclose conflicts of interest and to decline handling or reviewing manuscripts for which they may have a conflict of interest. The editors and reviewers of this article have no conflicts of interest.

Received for publication Oct 26, 2020; revisions received Oct 26, 2020; accepted for publication Oct 27, 2020; available ahead of print Nov 5, 2020.

Address for reprints: Leonard N. Girardi, MD, Department of Cardiothoracic Surgery, Weill Cornell Medicine, 1300 York Ave, New York, NY 10065 (E-mail: lngirard@ med.cornell.edu).

J Thorac Cardiovasc Surg 2022;164:610-1

$0022-5223 / \$ 36.00$

Copyright (c) 2020 by The American Association for Thoracic Surgery

https://doi.org/10.1016/j.jtcvs.2020.10.114
Check for updates

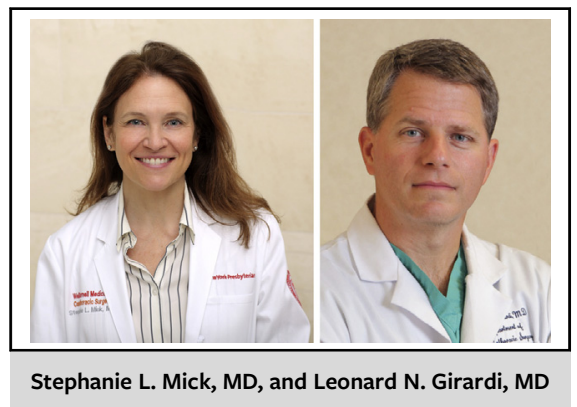

CENTRAL MESSAGE

In medical malpractice cases

involving aortic dissection, the most common alleged bases of

litigation were failure to diagnose

$(64.4 \%)$, delayed treatment

$(30.4 \%)$, and failure to test

$(28.1 \%)$.

and treatment pathways with catastrophic consequences. ATAAD ravages the aorta with a mortality of $1 \%$ per hour from onset to the time of operation. For those fortunate to get to operation, the mortality even within the experienced centers reporting to the International Registry of Aortic Dissection remains approximately $22 \% .^{2}$ Is it any wonder why dissection is so strongly associated with medical malpractice litigation? $?^{3,4}$ 